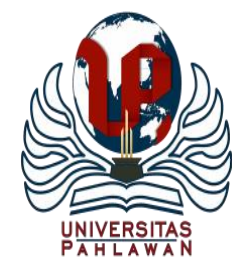

Jurnal Abdidas Volume 1 Nomor 3 Tahun 2020 Halaman 157 - 164

JURNAL ABDIDAS

Community Development Service on Educational and Health Sciences http://abdidas.org/index.php/abdidas

\title{
Adaptasi Pendampingan Kesehatan Di Masa Pandemi Covid 19 Studi Strategi Virtual Outreach PKBI Kota Semarang
}

\author{
Amrizarois Ismail $^{1}$, Muhammad Rofiq ${ }^{2}$, M. Afifun Na'im ${ }^{3}$, Isa Aulia Rohman ${ }^{4}$ \\ Universitas Katolik Soegijapranata Semarang, Jawa Tengah, Indonesia ${ }^{1}$ \\ Universitas Islam Negeri Walisongo Semarang, Jawa Tengah, Indonesia ${ }^{2}$ \\ PKBI Kota Semarang, Jawa Tengah, Indonesia ${ }^{3,4}$ \\ E-mail : amrizarois@unika.ac.id ${ }^{1}$ mrofiq@walisongo.ac.id ${ }^{2}$ Afif_pkbismg@yahoo.com ${ }^{3}$ \\ auliarohmanisa@gmail.com ${ }^{4}$
}

\begin{abstract}
Abstrak
Di tengah laju pandemi yang masih terus bertambah, pemerintah secara serta merta kini mulai menyerukan kebijakan pembatasan sosial untuk menanggulangi penularan. Hal ini tentu menjadi kendala dalam pendampingan kesehatan yang sebelumnya mengandalkan tatap muka yang memerlukan mobilitas yang cukup tinggi, untuk menjalin komunikasi intensive, untuk memastikan ODHA dan penderita penyakit lainya tetap patuh terhadap aturan kesehatan. PKBI Kota Semarang telah mengupayakan strategi baru, agar pendampingan kesehatan terutama pencegahan HIV Aids tetap berjalan dengan hasil maksimal. Diantara strategi yang telah dijalankan adalah Virtual Outreach atau dikenal dengan nama VO. Penelitian ini menggunakan metode penelitian kualitatif deskriptif untuk dapat melihat seberapa efektif adaptasi model pendampingan yang telah dilakukan. VO yang telah dijalankan PKBI Kota semarang menunjukan adanya peningkatan dibanding dengan metode tatap muka (TM). Hal itu menunjukan bahwa model adaptasi pendampingan kesehatan melalui metode Virtual yaitu VO cukup efektif untuk dijalankan.
\end{abstract}

Kata kunci: Covid 19, VO, HIV AIDS, PKBI, Kota Semarang

\begin{abstract}
During the still growing pandemic, the government immediately began to call for a social restriction policy to tackle transmission. This certainly becomes an obstacle in health assistance that previously relied on face-toface which requires high mobility to establish intensive communication to ensure PLWHA and other disease sufferers remain compliant with health regulations. PKBI Kota Semarang has pursued a new strategy, so that health assistance, especially HIV Aids prevention, continues to run with maximum results. Among the strategies that have been implemented are Virtual Outreach or also known as VO. This research uses descriptive qualitative research methods to be able to see how effective the adaptation of the assistance model has been done. VO which has been run by PKBI Kota Semarang shows an increase compared to the face-toface (TM) method. It shows that the adaptation model of health assistance through the Virtual method that is $V O$ is quite effective to run.
\end{abstract}

Keywords: Covid 19, VO, HIV AIDS, PKBI, Kota Semarang

Copyright (c) 2020 Amrizarois Ismail, Mohammad Rofiq, M. Afifun Na'im, Isa Aulia Rohman

$\triangle$ Corresponding author :

Address : Pawiyatan Luhur IV/1, Bendan Dhuwur, Semarang

ISSN 2721- 9224 (Media Cetak)

Email : amrizarois@unika.ac.id

ISSN 2721- 9216 (Media Online)

Phone : +625713989552

DOI: https://doi.org/10.31004/abdidas.v1i3.35 


\section{PENDAHULUAN}

Kasus HIV AIDS di Kota Semarang, Jawa Tengah dari tahun ke tahun terus mengalami kenaikan. Rata-rata ada kenaikan 500 orang atau penderita baru tiap tahunnya sejak 2011 (Agus Joko Mulyono, 2019). HIV AIDS sendiri merupakan virus yang menular melalui beberapa jalan, seperti transmisi seksual. Virus yang menyerang kekebalan tubuh manusia ini hingga kini belum ditemukan obatnya, hal ini berarti HIV akan terus hinggap dan menggerogoti orang tubuh dengan HIV (ODHA), terlebih bila tidak mengkonsumsi obat penghambat laju pertumbuhan Virus (ARV).

Untuk mendorong angka patuh terhadap anjuran minum obat bagi ODHA, maka diperlukan peran pendamping baik itu yang berasal dari sesama ODHA maupun relawan sosial non ODHA, hal ini tentu juga berlaku bagi upaya penanggulangan penyakit lainya. Persoalan kini muncul saat wabah baru kembali menyerang Indonesia dan dunia, apalagi kalo bukan Pandemi COVID-19. Dunia termasuk Indonesia saat ini tengah dihadapkan dengan masalah kesehatan yang sangat besar, yaitu persebaran Pandemi COVID-19. secara keseluruhan kasus pasien positif corona per Jum'at 10 Juli 2020 di Indonesia mencapai keterjangkitan sebesar 72.347 jiwa (Rohmana Kurniandari, 2020), dan belum bisa dipastikan berhendtinya laju penambahan angka keterjangkitanya. Pandemi COVID-19 ini sendiri merupakan wabah keterjangkitan virus corona yang awalnya berasal dari kota Wuhan di China dan hingga kini terus menyebar keseluruh Dunia. Di Indonesia sendiri, angka kasus keterjangkitan berasal dari DKI Jakarta hingga kemudian menjadi epicentrum dan kini terus menyebar hampir ke seluruh daerah di Indonesia. Tentu hal ini menjadi ancaman baru bagi kegiatan pendampingan kesehatan mengingat tenaga pendamping kesehatan juga memiliki mobilitas tinggi di lapangan.

Di tengah laju pandemi yang masih terus bertambah, pemerintah secara serta merta kini mulai menyerukan kehidupan New Normal, yang pada intinya mendorong kebiasaan baru, terutama kebiasaan hidup sehat seperti rajin cuci tangan dengan sabut, menggunakan APD seperti masker, hingga mengurangi mobilitas bepergian dan interaksi. Hal ini menarik untuk menjadi diskusi bersama, terutama terkait bagaimana penerapan pola New Normal untuk kegiatan pendampingan kesehatan mengingat sebelumnya memerlukan mobilitas yang cukup tinggi untuk menjalin komunikasi intensive untuk memastikan ODHA dan penderita penyakit lainya tetap patuh terhadap aturan kesehatan.

Salah satu kegiatan yang biasa dilakukan dalam masa New Normal adalah kegiatan virtual. Selain telah melakukan adaptasi kegiatan virtual seperti webinar, webmeeting dan webtrainig, petugas pendamping kesehatan juga mulai mengatur strategi untuk melakukan kegiatan penjangkauan dan pendampingan klien melalui metode virtual juga sebagai bentuk adaptasi masa pandemi COVID-19. Keefektifan pendampingan dengan media internet atau online sendiri sebelumnya telah banyak diulas dalam beberapa artikel, seperti contoh artikel dalam jurnal Jipsi yang berjudul konseling online sebagai upaya 
menangi maslah perundungan di kalangan anak muda oleh Irianti Mansyur (et al., 2019) yang menunjukan cukup efektifnya media internet dalam konseling dan sudah mulai lazim digunakan sejak 2008. Penelitian pendahuluan lain tentang preferensi keefektifan dari konseling online (King, Bambling, Reid, \& Thomas, 2006; Mallen et al., 2005). Hanley (2006) juga menyimpulkan bahwa konseling online memiliki potensi besar. Selanjutnya metode pendampingan dan penjangkauan klien ini kemudian dikenal dengan nama Virtual Outreanch (VO).

PKBI Kota Semarang adalah Perkumpulan Keluarga Berencana Indonesia (PKBI) Kota Semarang adalah salah satu cabang PKBI Jawa Tengah yang berdiri sejak tahun 1970. Fokus utama PKBI Kota Semarang adalah isu-isu kesehatan reproduksi. Kegiatan awal mula PKBI Kota Semarang adalah kegiatan layanan klinik seperti layanan keluarga berencana (kontrasepsi) dengan sistem kafetaria, pengobatan infeksi menular seksual (IMS) serta promosi kesehatan (M Taufiq Hidayat, 2017).

Di antara kegiatan PKBI yang menjadi role model kegiatan pendampingan kesehatan adalah kegiatan penanggulangan HIV AIDS dalam projek Global Fund New Funding Model (GF NFM).

Projek ini merupakan projek pendampingan negara berkembang dengan berbagai fokus permasalahan. Di Indonesia sendiri permasalahan yang menjadi fokus intervensi projek GF NFM ini adalah masalah kesehatan, yakni keterjangkitan Tuberkolosis dan HIV AIDS. PKBI Kota Semarang sendiri mendapatkan kepercayaan untuk menjalankan kegiatan pendampingan pencegahan
HIV AIDS di Kota Semarang dengan Kelompok sasaran diantaranya adalah: 1) lelaki seks lelaki atau men seks men (MSM), 2) transgender (TG) atau waria, 3) pengguna narkoba suntik (Penasun)/ People Who Inject Drug (PWID).

Kegiatan ini kurang lebih sudah berjalan sejak tahun 2016 dengan hasil yang cukup baik. Persoalan kemudian muncul ketika dunia dan Indonesia dilanda wabah pandemi COVID-19. Cepatnya penularan COVID-19 ini kemudian menjadi salah satu kehawatiran petugas pendamping kesehatan baik di PKBI Kota Semarang dan lainya. Untuk itu, PKBI Kota Semarang telah mengupayakan strategi baru, agar pendampingan kesehatan terutama pencegahan HIV Aids tetap berjalan dengan hasil maksimal. Diantara strategi yang telah dijalankan adalah Virtual Outreach atau dikenal dengan nama VO.

Hasil yang dicapai PKBI Kota Semarang dalam menjalankan VO ini terutama di masa pandemi merupakan hal yang menarik untuk diamati sebagai bentuk role model adaptasi pendampingan kesehatan di masa pandemi.

\section{METODE}

Penelitian ini menggunakan metode penelitian kualitatif deskriptif. Penelitian deskriptif kualitatif adalah penelitian yang menggambarkan atau melukiskan objek penelitian berdasarkan fakta-fakta yang tampak atau sebagaimana adanya (Sugiyono, 2016). Penelitian deskriptif kualitatif berusaha mendeskripsikan seluruh gejala atau keadaan yang ada, yaitu keadaan gejala menurut apa adanya pada saat penelitian dilakukan (J.Moleong, 2006). 


\section{HASIL DAN PEMBAHASAN}

\section{Penjangkauan melalui media Sosial /Virtual Outreach (VO)}

Strategi pelaksanaan program pencegahan HIV di Indonesia hingga saat ini masih menggunakan metode penjangkauan yang dilakukan oleh petugas kesehatan atau dalam hal ini disebut petugas lapangan. Tugas utama dari petugas lapangan adalah untuk mejalin komunikasi dengan kelompok dampingan atau klien secara langsung atau tatap mukan (TM), sehingga informasi tentang pencegahan penyakit, dalam hal ini HIV AIDS dapat tersampaikan. Namun, data evaluasi menunjukkan pendekatan tersebut hanya mampu mencakup 20\% komunitas MSM pada tahun 2011, dan pada tahun 2013 hanya mencapai 59\% komunitas yang ada (Spiritia, 2019).

Internet sebagai media yang menyediakan kelebihan dan dapat memberikan tempat yang aman dan tanpa takut untuk diketahui identitasnya bagi komunitas dampingan, disaat lingkungan dan masyarakat tidak mendukung keberadaan komunitas tersebut ditengah-tengah mereka, termasuk bagi orang yang positif HIV (ODHA), untuk berpartisipasi dalam pencegahan, perawatan dan pengobatan HIV. Memanfaatkan penggunaan media internet PKBI Kota Semarang bermaksud untuk mengembangkan, membuat dan menerapkan pendekatan alternatif, yaitu, penjangkauan secara virtual (virtual outreach) dan kampanye berbasis internet (cyber campaign) dengan harapan untuk lebih bisa menjangkau komunitas yang belum sebelumnya belum terlayani atau sulit dijangkau yang dikenal dengan kelompok MSM, TG, dan PWID tertutup.
Pendekatan ini dimaksudkan untuk melengkapi pendekatan yang sudah dilakukan, yaitu melalui penjangkauan tatap muka, sehingga implementasi program pencegahan HIV bagi komunitas MSM, TG, dan PWID bisa mencapai cakupan yang lebih banyak lagi.

\section{Ruang Lingkup VO}

Karena situasi tersebut, maka internet atau dunia maya juga bisa menjadi alat untuk melakukan penjangkauan/outreach. Meskipun belum ada studi yang spesifik dan sistematis khususnya tentang virtual outreach, namun dengan memperhatikan fakta semakin banyaknya teknologi ini diakses dan digunakan serta observasi anekdotal bahwa lebih banyak MSM yang tertutup yang mengakses internet, cara ini layak ditempuh. Internet outreach mempunyai banyak sebutan lain seperti virtual outreach, computer outreach, online outreach atau cyberspace outreach. Dalam hal ini, kita akan gunakan istilah virtual outreach.

Virtual outreach didefinisikan sebagai interaksi virtual antara PL dan individu atau sekelompok orang yang berperilaku risiko tinggi terhadap HIV dengan tujuan menyediakan: informasi dan pendidikan kesehatan, rujukan dan akses layanan, rekruitmen untuk testing dan pengobatan serta dukungan bagi pengurangan risiko terkait HIV (Spiritia, 2019).

Sama dengan outreach tradisional, virtual outreach juga menjangkau kelompok dampingan dimana mereka berada, dalam kasus ini di dunia maya. Pendidik kesehatan yang terlatih dan PL dapat menyediakan berbagai macam layanan melalui internet, termasuk: 
a. Pendidikan pencegahan

b. Konseling pengurangan risiko

c. Rujukan ke web informasi yang terpercaya

d. Rujukan ke sumber-sumber lokal seperti tempat-tempat tes, pengobatan dan kelompok dukungan

e. Rekruitmen ke dalam program pencegahan dan perawatan

f. Promosi perilaku pencarian kesehatan yang positif

g. Dukungan bagi komunitas berisiko di dunia maya.

Pesan-pesan kesehatan dapat dikirimkan ke kelompok-kelompok melalui instant messenging, chat rooms, situs jejaring sosial, situs jejaring seksual, menggunakan instant messaging untuk memberikan informasi, diposting di dalam bulletin board atau kepada individu-individu selama sesi pribadi satu lawan satu dan e-mail. Interaksi seperti ini tidak membutuhkan perjanjian, durasi dan intensitasnya dapat beragam.

\section{Langkah VO}

Ada beberapa tahapan yang dapat dilakukan dalam menjalankan Virtual Outreach, diantaranya adalah:

\section{Research disebut juga penelitian atau} pengamatan menjadi penting dilakukan, terutama untuk mengetahui segmentasi dan karakteristik informasi atau konten internet apa saja yang sering diakses oleh kelompok dampingan, termasuk karakteristik demografi mereka, pengetahuan-sikap-perilaku mereka terkait HIV dan AIDS, situs jejaring sosial dan seksual yang digunakan MSM, termasuk website dan kebutuhan umum segmen ini terkait HIV dan AIDS. Tempat-tempat online spesifik yang cocok untuk melakukan internet outreach harus diputuskan, termasuk waktu dan hari efektif untuk menjangkau mereka melalui internet.

2. Penetapan populasi sasaran perlu dilakukan berdasarkan hasil penjajakan di atas. Semakin spesifik populasi sasaran akan semakin baik. Segmen mana yang paling bisa dijangkau dan dilayani melalui internet outreach perlu ditentukan. Segmen yang terpenting adalah MSM yang sering menggunakan internet sebagai sarana komunikasi, mencari informasi dan mencari pasangan seks. Dan jika memungkinkan, segmen ini memang yang selama ini tidak terjangkau melalui outreach konvensional.

3. Memulai Komunikasi, Setelah tahapan diatas dilakukan, langkah yang harus dijalankan selanjutnya adalah memulai komunikasi. Dalam langkah ini, petugas dapat menggunakan media atau platform yang sesuai. Gunakan percakapan pembuka yang sesuai dengan karakteristik kelompok dampingan, selanjutnya berikan informasi secara persuasif terstruktur, dan cobalah menggunakan model komunikasi empati. Pada tahap akhir munculkan ajakan persuasif untuk didampingi dan akses layanan kesehatan secara mandiri secara lanjut.

\section{Efektifitas VO}

Seperti yang telah disampaikan sebelumnya bahwa kegiatan pendampingan kesehatan terutama HIV AIDS melalui outreach tatap muka hanya mampu mencakup 20\% komunitas MSM pada 
tahun 2011, dan pada tahun 2013 hanya mencapai $59 \%$ komunitas yang ada, di masa pandemi COVID-19 hal tersebut kini dirasa semakin menurun keefektifanya. Hal ini dikarenakan aturan Pembatasan sosial yang berlaku, sehingga PKBI Kota Semarang dan Lembaga pendamping kesehatan lainya tidak dapat mengumpulkan masyarakat khususnya klien atau dampingan guna melakukan pendampingan dan kegiatan pengembangan sumber daya manusia seperti diskusi, seminar dan pelatihan.

Semarang sendiri, dalam rangka menanggulangi penyebaran COVID-19 turut memberlakukan aturan Pembatasan Kegiatan Masyarakat (PIKM) yang juga membatasi jumlah masyarakat dalam berkerumun. Hal ini tentu mempengaruhi efektifikats kegiatan pendampingan kesehatan seperti di atas. Hal tersebut diperparah dengan adanya kehawatiran petugas pendamping kesehatan terhadap resiko tertular COVID-19. Untuk itu diperlukan berbagai alternatif, agar kegiatan pendampingan kesehatan tetap bisa menjalankan fungsinya, khususnya dalam pendampingan, rujukan klien, hingga pengembangan sumber daya manusia dalam upaya penanggulangan penyakit, dalam hal ini pelatihan atau training.

Kegiatan Virtual Outreach ini yang telah dilakukan di atas, bisa menjadi alternatif solusi untuk dapat menjalankan kegiatan diatas, hal ini dapat dilihat dari hasil kegiatan penjangkauan 3 (tiga) komunitas dampingan yaitu 1) MSM, 2) TG, dan 3) PWID melalui Virtual Outreah sebagaimana ditunjukan dalam gambar berikut:
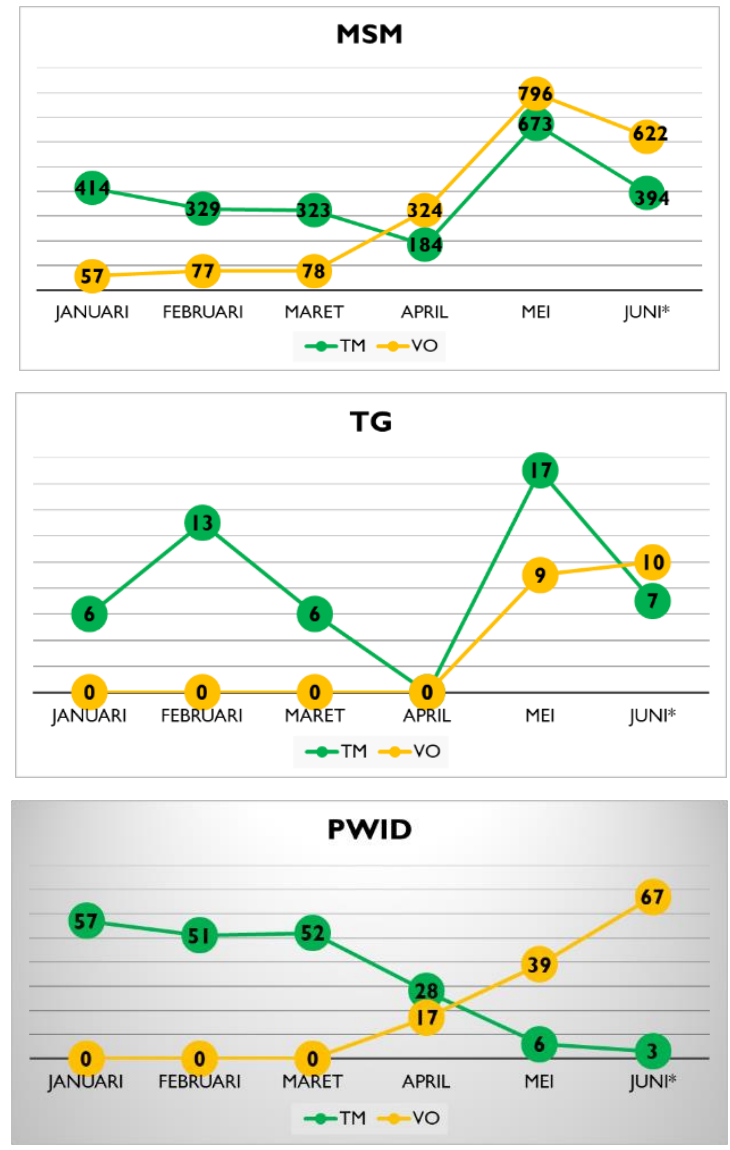

Gambar 1. Hasil VO Kelompok MSM, TG, dan PWID (Bank Data PKBI Kota Semarang)

Gambar tersebut merupakan grafik yang menunjukan dinamika penjangkauan menggunakan metode outreach tatap muka (TM) dan Virtual Outreach (VO).

Hasil menunjukan, pada kelompok MSM, TM mengalali penurunan hasil sejak masa pandemi COVID-19 melanda, dan puncaknya pada April, hasil TM mengalami penurunan dari 323 orang yang berhasil dijangkau menjadi 184 orang, dan mulai membaik kembali hingga kini memperlihatkan hasil 394 orang yang dijangkau pada bulan juni. Hal berbeda diperlihatkan hasil VO, hasil menunjukan peningkatan yang signifikan ketika memasuki masa pandemi COVID-19, hasil VO pada kelompok MSM sendiri 
menghasilkan peningkatan sejak bulan April mencapai 324 orang, dan terakhir mencapai 624 orang yang berhasil dijangkau pada juni.

Hasil serupa juga ditunjukan oleh kelompok TG dan PWID. Hasil penjangkauan tatap muka (TM) kelompok TG pada bulan juni mencapai 7 orang, sedangkan pada VO menunjukan hasil 10 orang yang dapat dijangkau. Pada kelompok PWID pun demikian, hasil penjangkauan tatap muka (TM) pada juni menunjukan angka 3 orang, sedangkan VO mencapai 67 orang PWID yang mampu dijangkau.

Hasil diatas sudah dapat menunjukan, bahwa model adaptasi penjangkauan Virtual Outreach (VO) yang dilakukan petugas kesehatan PKBI Kota Semarang menunjukan peningkatan hasil sejak masa pandemi COVID-19 melanda, yaitu kurang lebih pada bulan April. Hasil tersebut seyogyanya dapat dijadikan sebagai justifikasi keefektifan model adaptasi VO yang dilakukan dalam pendampingan kesehatan di masa pandemi. Pasalnya, hasil penjangkauan merupakan salah satu indikator utama dalam dunia pendampingan kesehatan, khususnya program pencegahan dan penanggulangan HIV AIDS.

\section{SIMPULAN}

Hasil pemaparan diatas setidaknya dapat disimpulkan bahwa PKBI Kota Semarang merupakan salah satu lembaga pendampingan kesehatan yang aktif melakukan pendampingan kesehatan terutama HIV AIDS. PKBI Kota semarang telah menjalankan strategi adaptasi pendampingan kesehatan di masa pandemi
COVID-19 berupa penjangkauan melalui media virtual atau disebut dengan Virtual outreach (VO).

Virtual outreach didefinisikan sebagai interaksi virtual antara petugas dan individu atau sekelompok orang yang berperilaku risiko tinggi terhadap HIV dengan tujuan menyediakan: informasi dan pendidikan kesehatan, rujukan dan akses layanan, rekruitmen untuk testing dan pengobatan serta dukungan bagi pengurangan risiko terkait HIV.

Dari hasil penjangkauan dimasa pandemi COVID-19 (sekitar bulan April) melalui VO yang telah dijalankan PKBI Kota semarang, menunjukan hasil VO dari 3 (tiga) komunitas kelompok dampingan yaitu MSM, TG, dan PWID menunjukan hasil yang peningkatan dibanding dengan metode tatap muka (TM). Hal itu menunjukan bahwa model adaptasi pendampingan kesehatan melalui metode virtual yaitu VO, cukup efektif untuk dijalankan, pasalnya selain menunjukan hasil yang meningkat, VO dinilai lebih aman terhadap resiko penularan COVID-19.

\section{UCAPAN TERIMA KASIH}

Terselenggaranya penelitian ini dengan topik Adaptasi Pendampingan Kesehatan di Masa Pandemi COVID-19 ini tidak lepas dari dukungan Perkumpulan Keluarga Berencana Indonesia (PKBI) Kota Semarang. Oleh karena itu, melalui kesempatan ini Tim peneliti mengucapkan terima kasih atas dukungan penuh sehingga bisa terlaksana dengan baik. 


\section{DAFTAR PUSTAKA.}

Agus Joko Mulyono. (2019, December 11). 500 Orang di Semarang Tertular HIV AIDS Tiap Tahun. Tagar.Id. https://www.tagar.id/500orang-di-semarang-tertular-hiv-aids-tiaptahun

Hanley, T. 2006. Developing youth-friendly online counseling services in the United Kingdom: A small scale investigation into the views of practitioners. Counselling and Psychotherapy Research, 6, 182-185.

Irianti Mansyur, A., Badrujaman, A., Imawati, R., Nur Fadhillah, D., Studi Bimbingan Konseling, P., Negeri Jakarta, U., Studi Manajemen Dakwah, P., Dakwah dan Ilmu Komunikasi, F., Syarif Hidayatullah Jakarta, U., \& Studi Pendidikan Pancasila dan Kewarganegaraan, P. (2019). KONSELING ONLINE SEBAGAI UPAYA MENANGANI MASALAH PERUNDUNGAN DI KALANGAN ANAK MUDA. Jurnal Pendidikan Ilmu Sosial.

J.Moleong, L. (2006). Metodologi penelitian Kualitatif. Kualitalif Sasial.

M Taufiq Hidayat. (2017, March). Profil PKBI Kota Semarang. PKBI Kota Semarang.

Rohmana Kurniandari. (2020, July 10). UPDATE Sebaran Virus Corona Indonesia Jumat (10/7/2020): 7 Provinsi Catat Lebih dari 100 Kasus Baru Artikel ini telah tayang di Tribunternate.com dengan judul UPDATE Sebaran Virus Corona Indonesia Jumat (10/7/2020): 7 Provinsi Catat Lebih dari 100 Kasus B. Tribunnews.Com. https://ternate.tribunnews.com/2020/07/10/up date-sebaran-virus-corona-indonesia-jumat1072020-7-provinsi-catat-lebih-dari-100kasus-baru

Spiritia, Y. (2019). PEDOMAN PENCATATAN \& PELAPORAN VIRTUAL OUTREACH [Indonesian HIV Response: Eliminating the AIDS Epidemic in Indonesia by 2030].

Sugiyono. (2016). Memahami Penelitian Kualitatif. Bandung: Alfabeta. 